\title{
PEMBERIAN TEPUNG DAUN SIRIH (Piper Betle L.) DALAM WAKTU LAMA UNTUK MENGOBATI MASTITIS SUBKLINIS PADA SAPI PERAH LAKTASI PASCA PUNCAK PRODUKSI
}

\section{SUPPLEMENTATION OF BETEL LEAF (Piper betle L.) MEAL IN LONG TERM TO TREAT SUBCLINICAL MASTITIS IN LACTATING DAIRY COWS POST-PEAK PRODUCTION}

\author{
Asep Sudarman*, Dedy Supriadin, dan Anuraga Jayanegara \\ Departemen IImu Nutrisi dan Teknologi Pakan, Fakultas Peternakan, Institut Pertanian Bogor, Bogor, \\ 16680
}

Submitted: 19 August 2016, Accepted: 16 January 2017

\section{INTISARI}

Penelitian ini bertujuan untuk memperoleh metode terbaik pemberian tepung daun sirih dalam waktu lama pada sapi perah laktasi pasca puncak produksi untuk mengobati mastitis subklinis. Rancangan percobaan yang digunakan dalam penelitian ini adalah rancangan acak lengkap dengan 4 perlakuan dan 3 ulangan dengan jumlah sapi perah laktasi yang digunakan sebanyak 12 ekor. Perlakuan yang diberikan yaitu P0 (tidak diberi tepung daun sirih, sebagai kontrol), P1 (pemberian tepung daun sirih setiap hari), P2 (pemberian tepung daun sirih berselang 1 minggu) dan P3 (pemberian tepung daun sirih dengan 3 minggu diberikan dan 1 minggu tidak diberikan). Sampling susu untuk uji kualitas dan mastitis subklinis dilakukan pada minggu ke 1, 7 dan 15. Parameter yang diukur adalah jumlah sel somatis, komposisi susu, produksi susu, konsentrasi immunoglobulin (lgG), kadar glukosa dan kadar trigliserida. Data dianalisis menggunakan analisis ragam (ANOVA) dan perbedaan nyata antar perlakuan dilakukan uji lanjut Duncan. Hasil penelitian menunjukkan bahwa jumlah sel somatis pada P0 (kontrol) mengalami peningkatan sebesar $17,22 \%$, sedangkan pada perlakuan P1, P2 dan P3 mengalami penurunan berturut-turut sebesar 95,74, 97,17 dan $89,03 \%$ pada akhir penelitian. Pemberian tepung daun sirih pada setiap perlakuan tidak berpengaruh nyata terhadap kualitas susu, IgG, glukosa dan trigliserida. Kesimpulan dari penelitian ini yaitu pemberian tepung daun sirih selang seminggu (P2) merupakan metode terbaik menurunkan jumlah sel somatis dan dapat meningkatkan produksi susu dengan tidak mengubah komposisi susu sekaligus dapat mengobati mastitis subklinis pada sapi perah.

(Kata kunci: Daun sirih, Mastitis subklinis, Produksi susu, Sapi perah, Sel somatis)

\section{ABSTRACT}

The objective of the experiment was to find the best giving method of betel leaf meal in long term to treat subclinical mastitis in lactating dairy cows post-peak production. The experimental design used was a completely randomized design with four treatments and three replicates using twelve cows. The treatments were P0 (without betel leaf meal, as control), P1 (giving of betel leaf meal every day), P2 (giving of betel leaf meal with one week interval) and P3 (Giving betel leaf meal for three weeks followed was not given for one week). Parameters measured were somatic cell count, milk composition, milk production, immunoglobulin (lgG), level of glucose and triglyceride. Data were analyzed by using analysis of variance (ANOVA) and the differences amongs treatments were examined by Duncan multiple range test. Results showed that number of somatic cells in the control (P0) increased by $17.22 \%$, whereas $P 1, P 2$ and P3 decreased somatic cell count by 95.74, 97.17 and $89.03 \%$, respectively. Supplementation of betel leaves did not significantly affect milk composition, $\lg \mathrm{G}$, glucose and triglyceride. It was concluded that supplementation of betel leaf meal with one week interval $(P 2)$ was the best method in lowering the number of somatic cells and increasing milk production without changing the composition of milk.

(Key words: Betel leaf, Dairy cow, Milk production, Somatic cell, Subclinical mastitis)

\footnotetext{
${ }^{*}$ Korespondensi (corresponding author):

Telp. +62 8129698772

E-mail: a_sudarman@yahoo.com
} 


\section{Pendahuluan}

Mastitis merupakan salah satu penyakit yang membahayakan pada sapi perah. Penyakit ini ditandai dengan peningkatan jumlah sel somatis, radang pada ambing (kelenjar mamae), rendahnya kualitas susu dan penurunan produksi susu pada sapi perah. Kasus mastitis pada sapi perah sangat tinggi terutama mastitis subklinis. Sampai saat ini kasus mastitis pada sapi perah masih menjadi masalah yang dihadapi oleh peternak, baik pada peternakan sapi perah rakyat maupun industri sapi perah. Untuk itu, diperlukan pemeriksaan secara khusus terhadap susu karena kejadian mastitis subklinis tidak menunjukkan gejala sakit tetapi terjadi penurunan produksi produksi susu dan kualitas susu yang banyak tidak diketahui oleh para peternak. Penyakit ini tersebar luas di berbagai belahan dunia. Di Indonesia pada tahun 2004 tercatat sekitar 65 sampai $75 \%$ dan pada tahun 2006 menjadi sekitar 75 sampai $83 \%$ (Sudarwanto et al., 2006) dan kemungkinan akan terjadi peningkatan terus dari tahun ke tahun.

Penyakit mastitis subklinis sangat berdampak pada produksi dan kualitas susu yang dihasilkan sehinggga akan mempengaruhi tingkat pendapatan peternak. Faktor penting yang mempengaruhi penyebaran mastitis pada sapi perah adalah terdapat mikroorganisme patogen dalam kuartir (puting susu) yang terinfeksi. Pengobatan mastitis biasanya menggunakan antibiotik secara langsung (intramamae), tetapi penggunaan antibiotik di beberapa negara sebagai bahan aditif telah dilarang. Hal ini disebabkan adanya residu dari penggunaan antibiotik yang membahayakan kesehatan manusia sebagai konsumen dari hasil peternakan dan bagi ternak itu sendiri. Maka perlu diterapkan penggunaan bahan herbal sebagai alternatif lain yang mengandung senyawa aktif sebagai antiseptik yang efektif sehingga aman bagi manusia dan ternak.

Daun sirih (Piper betle L.) sudah dikenal sejak lama di Indonesia. Hampir semua bagian tanaman sirih dapat digunakan sebagai obat, tetapi yang paling banyak digunakan adalah daunnya. Daun sirih memiliki daya antibakteri, antioksidan, dan fungisida untuk mengurangi jumlah bakteri dalam susu. Selain itu, daun sirih juga membantu dalam mengobati gangguan pencernaan, pendarahan, dan menyembuh- kan luka (Soewondo et al., 1991). Dari hasil kajian in vitro, Yamin et al. (2013) melaporkan bahwa penambahan $2 \%$ tepung daun sirih dalam konsentrat dapat menghambat pertumbuhan bakteri penyebab mastitis dan tidak mengganggu kondisi fermentasi rumen. Pemberian daun sirih dalam jangka pendek (Yamin, 2013) secara signifikan $(P<0,05)$ menurunkan sel somatik dan meningkatkan produksi susu, namun tidak mempengaruhi IgG. Namun pemberian daun sirih dalam waktu lama disinyalir dapat mengganggu sistem reproduksi, tetapi sistem reproduksi kembali normal ketika konsumsi daun sirih dihentikan. Penelitian ini bertujuan untuk mengevaluasi pengeruh pemberian tepung daun sirih dalam waktu lama pada sapi perah laktasi pasca puncak produksi untuk mengobati mastitis subklinis terhadap perubahan produksi susu dan untuk mendapatkan metode pemberian tepung daun sirih terbaik.

\section{Materi dan Metode}

\section{Lokasi dan waktu}

Penelitian ini dilaksanakan dari bulan Juli sampai Desember 2013 di peternakan sapi perah rakyat di daerah Kebon Pedes, Bogor. Analisis kualitas susu dilaksanakan di Laboratorium Kesehatan Masyarakat Veteriner dan Mikrobiologi Medik Terpadu, Fakultas Kedokteran Hewan, Institut Pertanian Bogor.

\section{Materi dan prosedur penelitian}

Ternak yang digunakan dalam penelitian ini adalah 12 ekor sapi perah peranakan Fries Holland laktasi ke-2 sampai ke-4 dengan bulan laktasi normal (bulan ke-3 sampai ke-5) yang menderita mastitis subklinis $(+++)$, dengan produksi susu ratarata 8 - 11 liter/ekor/hari. Pemerahan susu dilakukan setiap pagi (jam 03:00) dan sore (jam 16:00). Sampel susu untuk pengujian kualitas susu dan mastitis subklinis diambil dari pemerahan pagi pada minggu ke 1, 7 dan 15 untuk masing-masing kuartir. Pengujian mastitis dilakukan dengan menggunakan pereaksi IPB-1 (Sudarwanto et al., 1993), sampel yang terdeteksi mastitis subklinis kemudian dianalisa di Laboratorium Kesmavet IPB.

Sampling darah untuk pengukuran konsentrasi IgG, kadar glukosa dan trigliserida darah dilakukan pada akhir penelitian. Darah diambil pada pagi hari jam 
09.00-10.00 dari vena koksigial (ekor) dimana sapi perlakuan sudah diberi pakan 3 jam sebelumnya. Penambahan tepung daun sirih sebanyak $2 \%$ dari konsentrat dilakukan pada setiap pemberian pakan pagi dan sore yang dicampurkan pada konsentrat dengan tidak merubah konsentrat dan hijauan yang diberikan peternak.

\section{Rancangan percobaan dan analisis data}

Rancangan percobaan yang digunakan dalam penelitian ini adalah rancangan acak lengkap ( $R A L)$, dengan 4 perlakuan dan 3 ulangan. Perlakuan yang diterapkan dalam penelitian ini adalah, PO (kontrol, tidak diberi daun sirih), P1 (pemberian tepung daun sirih setiap hari), P2 (pemberian tepung daun sirih selang satu minggu), dan P3 (pemberian tepung daun sirih selama tiga minggu diikuti satu minggu tidak diberikan).

Parameter dalam penelitian ini adalah jumlah sel somatis yang diukur berdasarkan Sudarwanto dan Sudarnika (2008); kadar lemak, kadar protein, kadar bahan kering dan bahan kering tanpa lemak susu diukur berdasarkan Sanjaya et al. (2009); konsentrasi immunoglobulin G (IgG) mengikuti metode Burgess (1995); produksi susu diukur setiap minggu selama penelitian pada setiap kuartir.

Data yang diperoleh dianalisis menggunakan analisis ragam (ANOVA) dan jika terdapat perbedaan nyata diantara perlakuan maka dilakukan uji lanjut Duncan (Mattjik dan Sumertajaya, 2006). Analisis data dilakukan menggunakan software statistik SPSS 16.

\section{Hasil dan Pembahasan}

\section{Pengaruh penambahan tepung daun sirih terhadap jumlah sel somatis susu}

Sel somatis adalah kumpulan sel yang terdiri dari sel limfosit, neutrofit, monosit, makrofag dan runtuhan sel epitel. Peningkatan sel somatis merupakan salah satu indikator untuk memantau kesehatan kelenjar ambing dan status mastitis. Jumlah sel somatis lebih dari $400000 \mathrm{sel} / \mathrm{ml}$ disebut sebagai mastitis subklinis (Subronto, 2003).

Jumlah sel somatis pada kontrol (P0) mengalami peningkatan $(+17,11 \%)$ seiring dengan berjalannya waktu penelitian, dari $6.430 \times 1.000 \mathrm{sel} / \mathrm{mL}$ pada awal penelitian (minggu ke 1) menjadi $7.530 \times 1.000 \mathrm{sel} / \mathrm{mL}$ pada akhir penelitian (minggu ke 15).
Pemeriksaan awal pada perlakuan P2 menunjukkan jumlah sel somatis sebesar $5.295 \times 10^{3} \mathrm{sel} / \mathrm{ml}$ dan mengalami penurunan sebesar $670 \times 10^{3} \mathrm{sel} / \mathrm{ml}(-87,35 \%)$ pada pertengahan penelitian hingga $150 \times 10^{3}$ sel/ml $(-97,17 \%)$ pada akhir penelitian. Sedangkan pada perlakuan P1 dan P3 juga mengalami penurunan masing-masing $-95,74 \%$ dan $-89,03 \%$. Hasil sidik ragam menunjukkan pengaruh yang tidak nyata pada minggu ke 1 , tetapi sangat nyata $(P<0,01)$ terhadap penurunan sel somatis dari pengamatan pada minggu ke 7 dan 15. Pada Tabel 1 terlihat bahwa pemberian tepung daun sirih pada setiap perlakuan (P1, P2 dan P3) menurunkan jumlah sel somatis susu pada akhir penelitian. Tepung daun sirih mengandung zat aktif fenol yaitu kavikol 5,1 $8,2 \%$ dan eugenol $26,8-42,5 \%$, senyawa ini berfungsi sebagai bahan antimikroba karena adanya gugus $\mathrm{OH}$ yang bersifat racun terhadap mikroba dan semakin tinggi gugus $\mathrm{OH}$ yang ada pada senyawa tersebut akan semakin beracun bagi mikroba (Cowan, 1999). Pemberian tepung daun sirih selang seminggu (P2) mampu menurunkan jumlah sel somatis tertinggi.

\section{Pengaruh penambahan tepung daun sirih terhadap produksi susu}

Penurunan produksi susu merupakan dampak utama yang diakibatkan oleh mastitis subklinis, sebagai akibat dari kerusakan sel ambing yang terinfeksi oleh mikroorganisme patogen. Mastitis menekan pembentukan susu pada kwartir yang terinfeksi atau meradang sehingga menyebabkan penurunan produksi susu. Pola produksi susu selama penelitian disajikan pada Gambar 1 yang dapat digunakan untuk mengetahui persistensi produksi dari masing-masing perlakuan.

Pengaruh perlakuan terhadap rerata produksi susu harian menunjukkan perbedaan pada setiap minggu. Pemberian tepung daun sirih selama penelitian memberikan pengaruh yang berbeda nyata $(P<0,05)$, terutama pada minggu ke $5-10$ dan $13-14$, terhadap rerata produksi susu. Dengan kata lain pemberian tepung daun sirih selama 15 minggu dapat meningkatkan produksi susu sapi perah yang menderita mastitis subklinis $(+++)$. Hal tersebut disebabkan oleh kandungan zat aktif (kavikol) tepung daun sirih yang mampu membunuh bakteri penyebab mastitis subklinis sehingga 
infeksi terhadap sel-sel ambing menurun dan mengurangi peluruhan sel.

Pola produksi susu selama penelitian memperlihatkan pemberian tepung daun sirih (P1, P2 dan P3) mampu meningkatkan produksi, bahkan dapat mempertahankan persistensi produksi susu tinggi pada pengamatan setiap minggu. Pemberian tepung dauh sirih secara kontinyu (P1) baru mampu meningkatkan produksi susu pada minggu ke 6 , sedangkan peningkatan produksi susu pada perlakuan P2 dan P3 terjadi mulai minggu ke-4. Dari minggu ke 1 sampai minggu ke 3 pada perlakuan P2 dan P3 dan sampai minggu ke 5 pada P1 kemungkinan perlakuan pemberian tepung daun sirih melalui konsentrat dalam proses mempengaruhi sel-sel alveoli ambing yang terinfeksi. Yang mana hal ini berhubungan dengan penurunan jumlah sel somatis dan pengobatan (Benneddgaard et al., 2003). Kemampuan untuk mempertahankan produksi susu terus menerus dalam waktu yang lama (persistensi) akan meningkatkan total produksi susu yang lebih tinggi.

\section{Penambahan tepung daun sirih terhadap komposisi susu}

Perlakuan metode pemberian tepung daun sirih pada sapi yang menderita mastitis subklinis terhadap rerata kandungan lemak, protein, bahan kering (BK), dan bahan kering tanpa lemak (BKTL) diperlihatkan pada Tabel 2. Perlakuan tidak berpengaruh nyata terhadap kadar lemak susu. Kadar lemak susu kontrol $(2,29)$ tidak berbeda nyata dengan perlakuan pemberian tepung daun sirih P1 (2,71), P2 $(2,47)$ dan P3 (1.70). Pembentukan lemak susu tergantung dari jumlah pakan hijauan yang diberikan kepada ternak. Hijauan akan difermentasi di dalam rumen dan menghasilkan asam lemak terbang (VFA) terutama asam asetat. Asam asetat merupakan precursor yang langsung

Tabel 1. Pengaruh perlakuan terhadap jumlah sel somatis $(x 1.000 \mathrm{sel} / \mathrm{mL})$ (the effect of treatment on somatic cell count $(x 1.000$ cell/mL))

\begin{tabular}{lcccc}
\hline \hline \multirow{2}{*}{$\begin{array}{c}\text { Perlakuan } \\
\text { (treatment) }\end{array}$} & \multicolumn{2}{c}{ Minggu pengamatan (week of observation) } & \multirow{2}{*}{$\begin{array}{c}\text { Penurunan (\%) } \\
\text { (reduction (\%)) }\end{array}$} \\
\cline { 2 - 4 } P0 & 1 & 7 & 15 & $+17,11$ \\
P1 & $6.430 \pm 581,8$ & $6.560 \pm 557,1^{\mathrm{c}}$ & $7.530 \pm 1,207^{\mathrm{b}}$ & $-95,74$ \\
P2 & $9.390 \pm 7,399$ & $1.660 \pm 473,8^{\mathrm{b}}$ & $400 \pm 375,2^{\mathrm{a}}$ & $-97,17$ \\
P3 & $5.295 \pm 402,4$ & $670 \pm 727,6^{\mathrm{a}}$ & $150 \pm 38,29^{\mathrm{a}}$ & $-89,03$ \\
\hline
\end{tabular}

$\mathrm{P} 0=$ tanpa pemberian tepung daun sirih (without provision of betel leaf meal), $\mathrm{P} 1=$ pemberian tepung daun sirih berkelanjutan (continuous provision of betel leaf meal), $\mathrm{P} 2=$ pemberian tepung daun sirih dengan selang seminggu (provision of betel leaf meal with a week interval), P3 = pemberian tepung daun sirih selama tiga minggu diikuti satu minggu tidak diberi (provision of betel leaf meal for three weeks followed by one week were not given).

a,b,c Superskrip yang berbeda pada kolom yang sama menunjukkan perbedaan nyata $(P<0,05)($ different superscript at the same column indicate significant differences $(P<0.05)$ ).

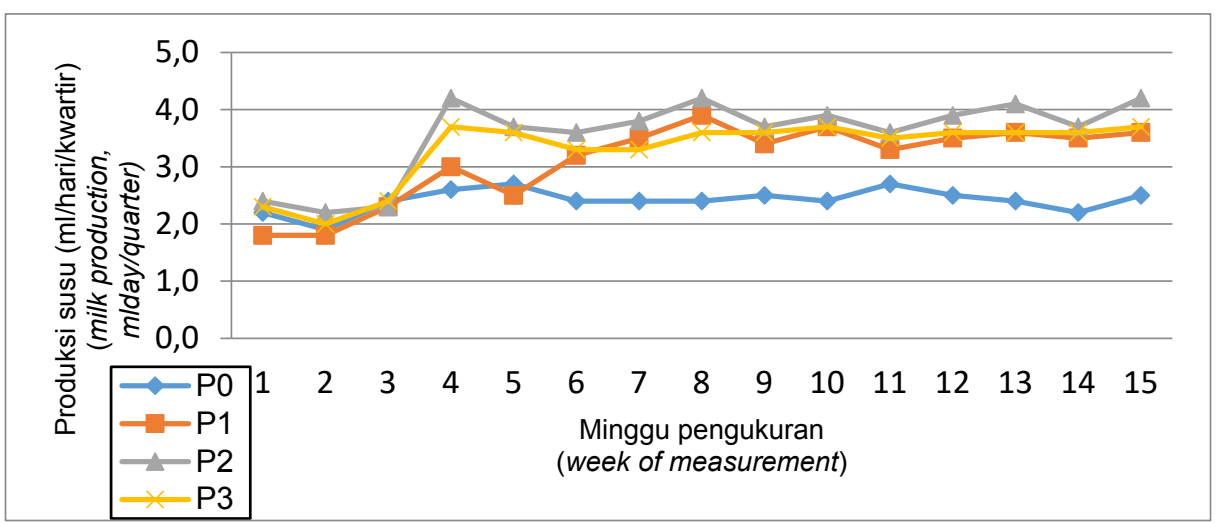

Gambar 1. Pola produksi susu dari setiap kwartir yang terkena mastitis subklinis selama penelitian

(the pattern of milk production of each quarter affected by subclinical mastitis during the study).

$\mathrm{P} 0=$ tanpa pemberian tepung daun sirih (without provision of betel leaf meal), $\mathrm{P} 1=$ pemberian tepung daun sirih berkelanjutan (continuous provision of betel leaf meal), P2 = pemberian tepung daun sirih dengan selang seminggu (provision of betel leaf meal with a week interval), P3 = pemberian tepung daun sirih selama tiga minggu diikuti satu minggu tidak diberi (provision of betel leaf meal for three weeks followed by one week were not given). 
digunakan untuk pembentukan lemak susu (Tyler dan Ensiminger, 2006). Dalam penelitian ini pakan yang diberikan sama untuk semua ternak. Soneo et al. (2009) melaporkan bahwa terjadi penurunan lemak susu sebesar $11 \%$ pada sapi yang terinfeksi mastitis subklinis. Laporan tersebut sesuai dengan hasil penelitian ini, kecuali pada P3. Badan Standardisasi Nasional (2011) dengan SNI 3141.1:2011 tentang persyaratan mutu, pengambilan contoh, pengujian, pengemasan dan pelabelan susu sapi segar menetapkan kandungan lemak susu minimum 3,0\% sehingga rerata kadar lemak yang diperoleh pada penelitian ini $(1,70-2,71)$ masih belum memenuhi syarat SNI. Untuk itu nampaknya pada peternakan ini perlu ditingkatkan pemberian pakan hijauannya.

Kandungan protein yang diberi perlakuan dengan penambahan tepung daun sirih tidak berbeda nyata dibandingkan dengan kontrol (P0) (Tabel 2). Kandungan protein yang diberi perlakuan dengan penambahan tepung daun sirih P1 $(2,94), \mathrm{P} 2$ $(2,63)$ dan P3 $(2,43)$ cenderung lebih rendah dibandingkan dengan kontrol/PO $(3,40)$. Kandungan sel somatis yang tinggi pada P0 mungkin berpengaruh terhadap tingginya kadar protein perlakuan kontrol (P0). Rajĉeviĉ et al. (2003) melaporkan adanya korelasi yang tinggi antara jumlah sel somatik dengan kandungan protein susu. Badan Standardisasi Nasional (2011) dengan SNI 3141.1:2011 tentang persyaratan mutu, pengambilan contoh, pengujian, pengemasan dan pelabelan susu sapi segar menetapkan kandungan protein minimum 2,8\% sehingga kadar protein susu yang diperoleh pada penelitian ini untuk P0 dan P1 sudah memenuhi syarat $\mathrm{SNI}$, sedangkan perlakuan $\mathrm{P} 2$ dan P3 belum memenuhi syarat SNI.

Pemberian tepung daun sirih tidak berpengaruh nyata $(P<0,05)$ terhadap rerata kandungan BK susu. Dalam penelitian ini BK susu yang dihasilkan berkisar antara 9,48\% sampai dengan 10,67\%. Lemak dan protein susu merupakan komponen utama BK susu, semakin tinggi lemak dan protein susu maka akan semakin tinggi BK susu. Pada Tabel 2 terlihat hubungan yang erat antara kandungan BK dengan jumlah kadar lemak dan protein susu. Selain BK, komposisi susu yang penting lainya adalah kandungan bahan kering tanpa lemak (BKTL).

Perlakuan pemberian tepung daun sirih tidak berpengaruh nyata terhadap BKTL
(Tabel 2). Nilai rerata BKTL paling tinggi adalah pada perlakuan kontrol $(\mathrm{P} 0)$ yaitu 8,02 yang kemudian diikuti berturut-turut oleh $\mathrm{P} 1$ $(7,96)$, P3 $(7,78)$ dan P2 $(7,46)$. Hal ini menunjukkan perlakuan pemberian tepung daun sirih tidak dapat meningkatkan kandungan BKTL. Hasil berbeda dilaporkan oleh Raluca dan Gavan (2010) bahwa jumlah sel somatis dapat menurunkan BKTL susu. Badan Standardisasi Nasional (2011) dengan SNI 3141.1:2011 tentang persyaratan mutu, pengambilan contoh, pengujian, pengemasan dan pelabelan susu sapi segar menetapkan kandungan BKTL minimum $7,8 \%$ sehingga rerata BKTL yang diperoleh pada penelitian ini, selain perlakuan $\mathrm{P} 2$, telah memenuhi syarat SNI.

\section{Pengaruh penambahan tepung daun sirih terhadap kadar immunoglobulin G (IgG), glukosa dan trigliserida}

Pengaruh perlakuan terhadap sistem kekebalan yang dihasilkan dalam penelitian ini disajikan pada Tabel 3 . Hasil analisis sidik ragam menunjukkan bahwa penambahan tepung daun sirih dalam jangka waktu yang lama tidak berpengaruh nyata $(P<0,05)$ terhadap rerata konsentrasi IgG selama perlakuan. Rerata nilai konsentrasi IgG kontrol $(0,959 \mu \mathrm{g} / \mathrm{mL})$ tidak berbeda nyata dengan P1 $(0,969 \mu \mathrm{g} / \mathrm{mL}), \mathrm{P} 2 \quad 0,962 \mu \mathrm{g} / \mathrm{mL})$ dan P3 $(0,974 \mu \mathrm{g} / \mathrm{mL})$. Hasil penelitian ini tidak berbeda dengan hasil penelitian Yamin et al. (2013) bahwa penambahan tepung daun sirih dalam ransum sapi perah yang terinfeksi mastitis subklinis tidak memberikan pengaruh terhadap sistem kekebalan tubuh namun lebih berpengaruh langsung terhadap pertumbuhan bakteri penyebab mastitis.

Pemberian tepung daun sirih tidak berpengaruh nyata $(P<0,05)$ terhadap kadar glukosa darah. Kadar glukosa darah masingmasing perlakuan adalah $\mathrm{PO}(56,17 \mathrm{mg} / \mathrm{dL})$, P1 (54,24 mg/dL), P2 (58,09 mg/dL) dan P3 $(54,59 \mathrm{mg} / \mathrm{dL})$. Glukosa pada ternak ruminansia merupakan hasil proses glukoneogenesis di dalam hati dari VFA hasil fermentasi dalam rumen. Dari hati glukosa diangkut oleh darah ke berbagai sel organ yang membutuhkan. Faktor yang mempengaruhi dan mengontrol kadar glukosa darah adalah pengaruh hormonal yang diantaranya adalah insulin dan glukagon. Hasil dalam penelitian ini menunjukkan bahwa suplai glukosa untuk pembentukan 
Tabel 2. Pengaruh penambahan tepung daun sirih terhadap rerata komposisi susu (lemak, protein, bahan kering (BK) dan bahan kering tanpa lemak (BKTL)) selama perlakuan (\%)

(the effect of adding betel leaves meal on milk composition (fat, protein, dry matter (DM) and non-fat dry matter NFDM) (\%))

\begin{tabular}{ccccc}
\hline \hline \multirow{2}{*}{$\begin{array}{c}\text { Perlakuan } \\
\text { (treatment) }\end{array}$} & \multicolumn{4}{c}{ Parameter* $^{*}$} \\
\cline { 2 - 5 } & Lemak (fat) & Protein (protein) & BK (DM) & BKTL (NFDM) \\
\hline P0 & $2,29 \pm 0,58$ & $3,40 \pm 0,56$ & $10,30 \pm 0,81$ & $8,02 \pm 0,33$ \\
P1 & $2,71 \pm 0,67$ & $2,94 \pm 0,41$ & $10,67 \pm 0,30$ & $7,96 \pm 0,53$ \\
P2 & $2,47 \pm 1,19$ & $2,63 \pm 0,28$ & $9,93 \pm 1,88$ & $7,46 \pm 0,90$ \\
P3 & $1,70 \pm 0,85$ & $2,43 \pm 0,67$ & $9,48 \pm 1,56^{\text {b }}$ & $7,78 \pm 0,87$ \\
\hline
\end{tabular}

${ }^{*}$ Rerata hasil pengukuran minggu ke 7 dan 15 (average of week $7^{\text {th }}$ and $15^{\text {th }}$ measurement results).

$\mathrm{P0}=$ tanpa pemberian tepung daun sirih (without provision of betel leaf meal), $\mathrm{P} 1=$ pemberian tepung daun sirih berkelanjutan (continuous provision of betel leaf meal), P2 = pemberian tepung daun sirih dengan selang seminggu (provision of betel leaf meal with a week interval), P3 = pemberian tepung daun sirih selama tiga minggu diikuti satu minggu tidak diberi (provision of betel leaf meal for three weeks followed by one week were not given).

${ }^{b}$ Superskrip yang berbeda pada kolom yang sama menunjukkan perbedaan nyata $(\mathrm{P}<0.05)($ different superscript in the same column indicate significant differences $(P<0.05))$.

Tabel 3. Pengaruh penambahan tepung daun sirih terhadap kadar immunoglobulin G, glukosa dan trigliserida (the effect of betel leaf meal addition on the levels of immunoglobulin G, glucose and triglyceride)

\begin{tabular}{lccc}
\hline \hline \multirow{2}{*}{$\begin{array}{c}\text { Perlakuan } \\
\text { (treatment) }\end{array}$} & \multicolumn{3}{c}{ Parameter } \\
\cline { 2 - 4 } P0 & $0,959 \pm 0,016$ & Glukosa $(\mathrm{mg} / \mathrm{dL})$ & Trigliserida $(\mathrm{mg} / \mathrm{dL})$ \\
P1 & $0,969 \pm 0,172$ & $56,17 \pm 1,14$ & $26,56 \pm 4,35$ \\
P2 & $0,962 \pm 0,009$ & $54,24 \pm 7,36$ & $26,56 \pm 5,46$ \\
P3 & $0,974 \pm 0,283$ & $58,09 \pm 4,19$ & $27,08 \pm 5,96$ \\
\hline
\end{tabular}

$\mathrm{P} 0$ = tanpa pemberian tepung daun sirih (without provision of betel leaf meal), $\mathrm{P} 1=$ pemberian tepung daun sirih berkelanjutan (continuous provision of betel leaf meal), P2 = pemberian tepung daun sirih dengan selang seminggu (provision of betel leaf meal with a week interval), P3 = pemberian tepung daun sirih selama tiga minggu diikuti satu minggu tidak diberi (provision of betel leaf meal for three weeks followed by one week were not given).

susu tidak dipengaruhi oleh pemberian tepung daun sirih.

Pemberian tepung daun sirih tidak berpengaruh nyata $(P<0,05)$ terhadap kadar trigliserida darah sapi perah. Kadar trigliserida kontrol $(26,56 \mathrm{mg} / \mathrm{dL})$ tidak berbeda jauh dengan perlakuan pemberian tepung daun sirih P1 (26,56 mg/dL) P2 (27,08 mg/dL) dan P3 $(26,04 \mathrm{mg} / \mathrm{dL})$. Hasil ini menunjukkan bahwa pemberian tepung daun sirih dengan metode pemberian yang berbeda tidak mengganggu konsentrasi metabolit darah di dalam tubuh sapi. Tepung daun sirih dengan zat anti bakterinya (kavikol) hanya berperan membunuh bakteri penyebab mastitis, sehingga sekretori sel yang dirusak oleh bakteri dapat mengalami penyembuhan yang selanjutnya dapat memproduksi susu kembali.

\section{Kesimpulan}

Pemberian tepung daun sirih dalam waktu lama pada sapi perah laktasi pasca puncak produksi tidak mengakibatkan pengaruh negative terhadap produksi susu.
Metode terbaik pemberian tepung daun sirih adalah pemberian selang satu minggu (P2) yang dapat meningkatkan produksi susu dengan menurunkan jumlah sel somatis dan tidak mengubah komposisi susu.

\section{Ucapan Terima Kasih}

Penelitian ini dapat terlaksana atas bantuan dana Hibah BOPTN IPB tahun 2013 atas nama Dr. Ir. Asep Sudarman, M.Rur.Sc.

\section{Daftar Pustaka}

Badan Standardisasi Nasional. 2011. Susu Segar-Bagian 1: Sapi. SNI 3141.1:2011.

Benneddgaard, T. W., C. Enevoldsen, S. M. Thamsborg, and M. Vaarst. 2003. Effect of mastitis treatment and somatic cell counts on milk yield in Danish Dairy Cows. J. Dairy Sci. 86: 3174-3183.

Burgess, G. W. 1995. Teknologi ELISA dalam Diagnosis dan Penelitian. Penerjemah: W. T. Artama. Gajah Mada University Press, Yogyakarta. 
Cowan, M. M. 1999. Plant product as antimicrobial agents. Clinical Microbiology Reviews 12: 564-582.

Mattjik, A. A., M. Sumertajaya. 2006. Perancangan Percobaan dan Aplikasi SAS dan Minitab. Jilid I. Ed. 2. IPB Press, Bogor.

Rajĉeviĉ, M., K. Potoĉnik and J. Levstek. 2003. Correlations between somatic cells count and milk composition with regard to the season. Agriculturae Conspectus Scientificus 68: 221-226.

Raluca, P. E. and C. Gavan. 2010. Influence of bulk milk somatic cell count on cow milk composition. Analele Universitati din Craiova, seria Agricultura Montanologie - Cadastru. XL/1: 171 174.

Sanjaya, A. W., M. Sudarwanto, D. W. Lukman, T. Purnawarman, H. Latif, dan R. R. Soejoedono. 2009. Penuntun Praktikum Hygiene Pangan Asal Hewan. Bagian Kesmavet, Fakultas Kedokteran Hewan, IPB, Bogor.

Soewondo, S., Sidik, R. S. Sumadilaga, dan R. M. Soelarko. 1991. Aktivitas antibakteri daun sirih (Piper bitle Linn). terhadap bakteri ginggivitis dan bakteri pembentuk plak/karies gigi (Streptococcus mutans). Warta Tumbuhan Obat 1: 1-4.

Sonea, C., D. Colceri and V. Bacila 2009. Research on sublinical mastitis effect on milk quality. Lucrări ştiinţifice Zootehnie şi Biotehnologii. 42: 337340.
Subronto. 2003. Ilmu Penyakit Ternak (Mammalia). Ed. 2. Gajah Mada University Press, Yogyakarta.

Sudarwanto M, dan E. Sudarnika. 2008. Hubungan antara $\mathrm{pH}$ susu dengan jumlah sel somatis sebagai parameter mastitis subklinis. Media Peternakan 31: 107-113.

Sudarwanto, M., C. S. Leksmono, D. W. Lukman dan M. Fakhrudin. 1993. Laporan Penelitian Pengembangan Metode dan Pereaksi untuk Deteksi Mastitis Subklinis. PAU Bioteknologi IPB.

Sudarwanto, M., H. Latif, and M. Noordin. 2006. The relationship of the somatic cell counting to sub-clinical mastitis and to improve milk Quality. $1^{\text {st }}$ International AAVS Scientific Conference. Jakarta, July $12-13$

Tyler, H. D. and M. E. Ensminger. 2006. Dairy Cattle Science. $4^{\text {th }}$ edn. Pearson Prentice Hall, Upper Saddle River, New Jersey.

Yamin, A. A., A. Sudarman, and D. Evvyernie. 2013. In vitro rumen fermentation and anti mastitis bacterial activity of diet containing betel leaf meal (Piper betle L.). Media Peternakan 36: 137-142. DOI: 10.5398/medpet.2013.36.2.137.

Yamin, A. A. 2013. Penambahan tepung daun sirih (Piper Betle L.) dalam ransun untuk mengobati dan mencegah penyakit mastitis subklinis pada sapi perah. Tesis, Sekolah Pascasarjana IPB, Bogor. 